\title{
RESPONSIBILITY OF COMPANIES IN INTERNATIONAL CRIMINAL LAW
}

\author{
FERENC SÁNTHA*
}

\begin{abstract}
In the paper, after outlining the criminological background, namely the corporate criminality in the field of core international crimes and some possible arguments in favour of criminal accountability of corporations on an international level, the case law of the International Military Tribunal at Nuremberg and the so-called subsequent Nuremberg trials is introduced. Finally, the third part is devoted to examine the questions of the codification process of the Statute of the International Criminal Court in relation to the organizational liability, putting the emphasis on answering the question: was there and is there an international court or tribunal that can exercise criminal jurisdiction over corporations?
\end{abstract}

Keywords: International criminal law, Criminal liability of legal persons for core international crimes, Crimes under international law, Corporate criminal liability in international criminal law, International Criminal Court

\section{INTRODUCTION}

The topic of my presentation is 'Responsibility of companies in international criminal law', but it should be emphasized in advance that I will not address all mechanisms of the concept of criminal liabilty of legal persons under international (criminal) law but will focus only on the international corporate criminal liability for the core international crimes: genocide, crimes against humanity and war crimes.

\section{CORPORATE CRIMINALITY IN THE FIELD OF CORE INTERNATIONAL CRIMES}

Today, it can be stated that the criminal liability of legal persons is a generally recognized principle in domestic criminal law, both in common law and civil law countries. ${ }^{1}$ Moreover, a number of international instruments, including UN conventions and EU directives, provide for corporate liability for the so-called transnational crimes $^{2}$, and the Universal Declaration of Human Rights can also be applied to legal

* Associate Professor, University of Miskolc, Faculty of Law, Institute of Criminal Sciences, Department of Criminal Law and Criminology.

1 In contrast to most of the continental European countries, in Germany only natural persons are presently subject to criminal liability.

2 Legal acts of the EU and other international organizations obligate states to take the appropriate measures to ensure that legal persons may be held accountable for criminal offences committed within their institutional frameworks. See e.g. Directive (EU) 2017/541 of the European Parliament and of the Council of 15 March 2017 on combating terrorism 
entities, making it possible to hold corporations liable for human rights abuses. ${ }^{3}$ A situation where a corporation can and should be liable for criminal offences at the national level but is not prosecuted internationally for the most serious international crimes would be difficult to justify.

Corporations, especially transnational corporations with their widespread crossborder activity have in the last decades become generators of international trade and globalization. ${ }^{4}$ These enterprises wield tremendous financial and political power ${ }^{5}$ which is not always used for noble goals and the negative consequences of the corporate activity can be qualified as criminal offences. The first and one of the most important preliminary questions is: Can we imagine a situation where the abovementioned core international crimes are committed within the framework of a corporation, namely a war crime is committed by the leader (or member or employee) of the corporation and a financial advantage, a profit of the crime appears for the corporation?

Historical experiences and the international practice show that the answer is definitely yes. These crimes can be called "organizational crimes", which constitute a form of collective criminality. E.g. the statutory element of crimes against humanity is the widespread or systematic attack against civilians and the common policy behind the attack. The attack must be committed against a civilian population, which necessarily implies some sort of plan, ${ }^{6}$ and crimes against humanity are inhumane acts "instigated or directed by a Government or by any organisation or group". This is also a characteristic feature of genocide which is usually a well-prepared crime that requires concerted planning and action ${ }^{8}$, and the commission of genocide usually presupposes certain degree of organisation and planning. Finally, this is also true in case of war crimes, which are often committed as a part of a large-scale commission or as a part of a policy. ${ }^{9}$

The commission of core international crimes presupposes the participation of various actors and logistics: "it must be planned, administrated, funded, and carried out; arms and other equipment must be provided; and complex logistics must be

and replacing Council Framework Decision 2002/475/JHA and amending Council Decision 2005/671/JHA.

3 ClaPham, Andrew: Human Rights Obligations of Non-State Actors. Oxford University Press, Oxford, 2006, p. 61.

4 VAN DEN HERIK, Larissa - ČERNIČ, Jernej Letnar: Regulating Corporations under International Law. Journal of International Criminal Justice, 8, 2010, p. 725.

5 Stortchкova, Desislava: Towards Corporate Liability in International Criminal Law. Intersentia, 2010, p. 1.

6 Kayishema Judgement, at para 125. (Trial Chamber ICTR-95-1)

7 ILC Draft Code of Crimes Art. 18 para. 5 of commentary.

8 FAUCHALD, Kristian - STIGEN, Jo: Corporate Responsibility Before International Institutions. The Geo. Wash. Int'l L. Rev., Vol. 40, 2009, p. 1033.

9 See the Art. 8 (1) of the Statute of the ICC: „, The Court shall have jurisdiction in respect of war crimes in particular when committed as part of a plan or policy or as part of a large-scale commission of such crimes." 
arranged." $" 10$ There are several core international crimes which have economic dimension, ${ }^{11}$ e.g. crimes againts humanity like forced labour and enslavement, war crimes like seizure of enemy property, pillaging and plundering, deployment of child soldiers, or using land mines. Corporations can provide the necessary weapons for the armed conflict or provide the chemicals needed for the production of toxic weapons.

According to Kaleck and Saage-Maaß, there are two main typical scenarios in which business actors can participate in international crimes:

- the cooperation of corporations with military regimes and dictatorships: (i) profiting from state violance; (ii) facilitating international crimes of a regime by providing the means for abuses; (iii) direct support of repressions;

- the involvement of corporations in (civil) war and other conflict zones: (i) fueling conflict through the provision of goods and illicit funds; (ii) providing military and intelligence services. ${ }^{12}$

In conclusion, it can be stated that corporate criminality is a reality in the area of international crimes. I note that there are other arguments in favour of prosecuting the corporate entity itself, e.g. corporate liability would facilitate restitution for victims; collective action is likely to result in greater harm than individual action; the individual actions of each corporate employee may be insufficient to hold any one of them liable under international law, even though a wrong has clearly been committed; effective deterrence of collective actions requires systemic punishment. ${ }^{13}$

In the following, the historical experiences will be outlined.

\section{HISTORY}

Even though examples of serious corporate crimes can be found as early as the 19th century ${ }^{14}$, the idea to focus on corporations in the context of prosecuting international crimes did not originate until the end of World War II, the case law of the International Military Tribunal at Nuremberg and the so-called subsequent Nuremberg trials.

\section{a) The International Military Tribunal}

According to Article 9 of the Nuremberg Charter, "At the trial of any individual member of any group or organisation the Tribunal may declare (in connection with

10 FAUCHALD - STIGEN: 2009, p. 1033.

11 NeRLICH, Volker: Core Crimes and Transnational Business Corporations. Journal of International Criminal Justice, 8, 2010, p. 900.

12 KALECK, Wolfgang - SAAGE-MAAß, Miriam: Corporate Accountability for Human Rights Violations Amounting to International Crimes. Journal of International Criminal Justice, 8, 2010, pp. 703-709.

13 SLYE, Ronald, C: Corporations, Veils, and International Liability. 33 Brook. J. Int'l L., 2008, p. 960.

14 See the crime of genocide, slavery and other human rights abuses committed in the framework of the Dutch East India Company and the British East India Company. KELLY, Michael J.: Prosecuting Corporations for Genocide. Oxford University Press, 2016, pp. 17-26. 
any act of which the individual may be convicted) that the group or organisation of which the individual was a member was a criminal organization". Based on the above declaration, the national authorities had the right to bring the member of the organisation to trial. ${ }^{15}$

The mechanism of the concept of criminal organisations was to establish the responsibility of the group or organisation in the first place and subsequently punish the members for the crimes committed in the framework of that organisation, but on the basis of individual guilt. ${ }^{16}$ Several political or military groups and organisations were declared criminal by the IMT, e.g. the Gestapo, the SS and the Leadership Corps of the Nazi Party, and the national courts and military tribunals relied on this doctrine in the subsequent trials of individuals.

The question is whether this solution can be regarded as a form of criminal liability of corporations?

I am afraid that the answer is no. This is due to the facts that - as van den Herik pointed out - the entities that were declared criminal were not corporations but political or military legal persons (1); The organizations declared criminal were never really tried as such before the Nuremberg Tribunal and it could not impose a penalty on the organizations as such (2); Finally, the organizations were already dissolved at the moment of the declaration of the IMT (3) ${ }^{17}$ Thus, declaring an organization criminal can be seen as a moral condemnation; the purpose behind this concept was to facilitate the prosecution of the organization's members.

b) Three of the cases ${ }^{18}$ of the so-called subsequent Nuremberg trials are worth mentioning, because the common feature of these cases was that serious international crimes were committed within the framework of a large corporation and a massive profit was made from the crimes.

The first is the Flick-case, in which the high-ranking corporate officers were charged with war crimes and crimes against humanity for their participation in the slave-labour programme and plundering of public and private property. In the case of I.G. Farben, five directors of the large German chemical firm, I.G. Farben were

15 See the Article 10 of the Charter: "In cases where a group or organization is declared criminal by the Tribunal, the competent national authority of any Signatory shall have the right to bring individual to trial for membership therein before national, military or occupation courts. In any such case the criminal nature of the group or organization is considered proved and shall not be questioned." https://avalon.law.yale.edu/imt/im tconst.asp\# (15. 2. 2021).

16 BIGALKE, Henning: Criminal responsibility of corporations in international law. University of Cape Town, 2013, p. 37.

17 VAN DEN HERIK, Larissa: Subjecting Corporations to the ICC regime: Analyzing the Legal Counterarguments. January, 22nd 2012, p 4, available at SSRN: https://ssrn.com/ abstract $=1989849$ (12. 2. 2021).

18 The cases (Trials of War Criminals Before the Nuernberg Military Tribunals Under Control Council Law No. 10.) are available online at https://phdn.org/archives/www.mazal.org/NMT-HOME.htm. 
convicted for the use of slave labour and plundering. There was the same situation in the Krupp-case. ${ }^{19}$

Finally, it is worth mentioning one more case, the infamous Ziklon B case, tried by the British Military Court in Hamburg. The court convicted the owner and the general manager of the company for aiding and abetting murder as a war crime. The company supplied concentration camps with Ziklon B which was used by the Nazis in the gas chamber during the Holocaust. ${ }^{20}$

What conclusions can be drawn from these cases?

It is a clear fact that the defendants of these cases were natural persons, not the companies, since the courts had no jurisdiction over legal persons as such, but the cases of great importance for several reasons, I mention only one:

The court decisions state that war crimes and crimes against humanity were committed by corporations. In the Farben case, the court explicitly stated that Farben as a legal entity has violated the prohibitions of international law. ${ }^{21}$ On the basis of these findings it may be concluded that corporations have obligations under international law, the prohibition of the commission of war crimes and crimes against humanity applies not only natural, but also legal persons.

Although the above-mentioned defendants were natural persons and not legal entities, these cases can be considered not only the first examples of prosecuting the heads of business on an international level but the starting point for corporate responsibility for the core international crimes.

\section{THE Rome Statute of THE InTERnational Criminal COURT}

After World War II, serious international crimes were committed in many parts of the world, but the perpetrators were rarely prosecuted and sentenced. The relative impunity of the actual perpetrators impeded any discussion about the liablity of other actors, including corporations. ${ }^{22}$ But in 1993 and 1994, two ad hoc international criminal tribunals were established, the ICTY and the ICTR. The statutes of these tribunals authorize the tribunals to prosecute individuals but not legal entities. However this does not mean that we cannot find a case in which a corporation was involved in the commission of a crime. For example, in the Nahimana case before the ICTR, two directors of the RTLM Radio Station were convicted by the Tribunal for incitement to genocide committed as part of the corporate activity of the station.

The historic moment arrived in 1998, when the diplomatic conference in Rome for the purpose of creating an international criminal court started its work. The negotiations on the ICC offered a new opportunity for the international community to establish an international mechanism for prosecuting corporations. The most important country that supported the idea of corporate criminal responsibility as part of

19 In the Krupp case, Alfried Krupp and other executives of the Krupp firm were convicted for crimes wirelating to plunder, spoliation and the use of forced labour.

20 KALECK - SAAGE MAAß: 2010, p. 701.

21 BIGALKE: 2013, p. 39.

22 KALECK - SAAGE MAAß: 2010 p. 702. 
the Rome Statute was France. French criminal law traditionally accepts that corporations can be held liable for criminal acts and the Criminal Code of France has regulated the liability of organisations since 1994.

Thus France, supported by other states, submitted a proposal that would subject legal entities to the ICC's jurisdiction. As a result of this proposal, the draft Statute contained a provision providing the Court jurisdiction over legal persons. Draft Article 23 , paragraphs 5 and 6 , provided that:

"[23(5) The Court shall have jurisdiction over legal persons, with the exception of States, when the crimes committed were committed on behalf of such legal persons or by their agencies or representatives.

23 (6) The criminal responsibility of legal persons shall not exclude the criminal responsibility of natural persons who are perpetrators or accomplices in the same crimes.]"

As we can see, the regulation is rather laconic: international criminal responsibility may be attributed to "legal persons", except states; the natural person who is the offender can be the representative or agency of the legal person; and the principle of parallel liability is declared.

Surprisingly, on 16th June 1998, the second day of the conference, France submitted a new and completely different proposal on organisational responsibility (Article 23) which was more in line with the Nuremberg precedent. ${ }^{23}$

"5. When the crime was committed by a natural person on behalf or with the assent of a group or organization of every kind, the Court may declare that this group or organization is a criminal organization.

6. In the cases where a group or organization is declared criminal by the Court, this group or organization shall incur the penalties referred to in article 76, and the relevant provisions of articles 73 and 79 are applicable.

In any such case, the criminal nature of the group or organization is considered proved and shall not be questioned, and the competent national authorities of any State party shall take the necessary measures to ensure that the judgement of the Court shall have binding force and to implement it."

This proposal has strongly criticized which has led France to modify it and a compromised final version (on 3 July 1998) was inserted into the final draft text:

„5. Without prejudice to any individual criminal responsibility of natural persons under this Statute, the Court may also have jurisdiction over a juridical person for a crime under this Statute. Charges may be filed by the Prosecutor againts a juridical person, and the Court may render a judgement over a juridical person for the crime charged, if:

23 VAN DEN HERIK: 2012, p. 6. 
a. The charges filed by the Prosecutor againts the natural person and the juridical person allege the matters referred to in subparagraphs (b) and (c); and

$b$. The natural person charged was in a position of control within the juridical person under the national law of the State where the juridical person was registered at the time the crime was committed; and

c. The crime was committed by the natural person acting on behalf of and with the explicit consent of that juridical person and in the course of its activities; and $d$. The natural person has been convicted of the crime charged."

The term "legal person" was replaced by the term "juridical person" which is defined in a separate provision. ${ }^{24}$ The natural person who engage the liablilty of the entity should be "in a position of control within the juridical person" and while committing the crime, the natural person should be "acting on behalf of and with the explicit consent of that juridical person and in the course of its activities". Sanctioning of the natural person is the precondition of the liability of the legal person.

Finally, and I have to say, unfortunatelly no general agreement could be reached about the text and France, for reasons of time, withdrew the proposal, and now the Rome Statute authorizes the ICC to prosecute only natural persons. ${ }^{25}$

\section{Closing Remarks}

In conclusion, it should be stated that there is no known case in which an international criminal court has established the liability of a legal person. This finding is true, despite the fact that a "hybrid" criminal tribunal, the Special Tribunal for Lebanon held a corporation accountable for the offense of contempt of court and imposed a criminal sanction against the company. ${ }^{26}$ As Nerlich put it: "corporate liability for core international crimes is an issue de lege ferenda, not de lege lata". But I am optimistic, it is only a matter of time before international criminal law regulates corporate criminality and the issue of corporate liability could be the next project in the following Review Conference of the Rome Statute.

\section{LIST OF LITERATURE}

[1] BIGALKE, Henning: Criminal responsibility of corporations in international law. University of Cape Town, 2013.

24 "For the purpose of this Statute, ,juridical person” means a corporation whose concrete, real or dominant objective is seeking private profit or benefit, and not a State or other public body in the exercise of State authority, a public international body or an organization registered, and acting under the national law of a State as a nonprofit organization."

25 "The Court shall have jurisdiction over natural persons pursuant to this Statute." [Article 25 (1) "Individual criminal responsibility"].

26 Case of Al Akhbar, STL-14-06. 
[2] Clapham, Andrew: Human Rights Obligations of Non-State Actors. Oxford University Press, Oxford, 2006.

[3] Fauchald, Kristian - STIGEN, Jo: Corporate Responsibility Before International Institutions. The Geo. Wash. Int'l L. Rev., Vol. 40, 2009.

[4] KALECK, Wolfgang - SAAGE-MAAß, Miriam: Corporate Accountability for Human Rights Violations Amounting to International Crimes. Journal of International Criminal Justice, 8, 2010.

[5] Kelly, Michael J.: Prosecuting Corporations for Genocide. Oxford University Press, 2016.

[6] NerLICH, Volker: Core Crimes and Transnational Business Corporations. Journal of International Criminal Justice, 8, 2010.

[7] SLYE, Ronald, C: Corporations, Veils, and International Liability. 33 Brook. J. Int'l L., 2008.

[8] Stoitchkova, Desislava: Towards Corporate Liability in International Ciminal Law. Intersentia, 2010.

[9] VAN DEN HERIK, Larissa - ČERNIČ, Jernej Letnar: Regulating Corporations under International Law. Journal of International Criminal Justice, 8, 2010.

[10] VAN DEN HERIK, Larissa: Subjecting Corporations to the ICC regime: Analyzing the Legal Counterarguments. January, 22nd 2012. 